$12-1-2020$

\title{
How to Attract Your Students to Your Games: The Difference of Mediating Effect of Psychic Income on the Relationship between Points of Attachment and Behavioral Attributes
}

\author{
Jinwook Chung \\ Winthrop University, chungj@winthrop.edu \\ Yong-Chae Rhee \\ Washington State University \\ Wonyoung Kim \\ Wichita State University
}

Follow this and additional works at: https://trace.tennessee.edu/jasm

Part of the Education Commons, Social and Behavioral Sciences Commons, and the Sports Management Commons

\section{Recommended Citation}

Chung, Jinwook; Rhee, Yong-Chae; and Kim, Wonyoung (2020) "How to Attract Your Students to Your Games: The Difference of Mediating Effect of Psychic Income on the Relationship between Points of Attachment and Behavioral Attributes," Journal of Applied Sport Management: Vol. 12 : Iss. 2.

https://doi.org/10.7290/jasm120206

Available at: https://trace.tennessee.edu/jasm/vol12/iss2/6

This article is brought to you freely and openly by Volunteer, Open-access, Library-hosted Journals (VOL Journals), published in partnership with The University of Tennessee (UT) University Libraries. This article has been accepted for inclusion in Journal of Applied Sport Management by an authorized editor. For more information, please visit https://trace.tennessee.edu/jasm. 


\title{
How to Attract Your Students to Your Games
}

The Difference of Mediating Effect of Psychic Income on the Relationship between Points of Attachment and Behavioral Attributes

\author{
Jinwook Jason Chung \\ Yong-Chae Rhee \\ Wonyoung Kim
}

\begin{abstract}
The purpose of the current study was to examine the impact of the points of attachment with the mediating impact of college students' psychic income on their attendance and word-of-mouth behavioral intentions. A total of 537 samples were collected from college students at a mid-sized southwest university in the United States. A CFA was conducted to evaluate the psychometric properties of the scales. The hypothesized model was tested using a SEM with AMOS 26 software. Additionally, a bootstrapping method was employed to determine the indirect effect of the mediating variable of psychic income on the relationship between points of attachment and behavioral intentions as well as points of attachment and word of mouth. The results reveal that psychic income mediated the proposed relationships.
\end{abstract}

Keywords: Athletic administration, collegiate sport, consumer behavior, marketing, word of mouth

Jinwook Chung is an assistant professor and program director of Sport Management at Winthrop University.

Yong-Chae Rhee is an associate professor in the Sport Management Program at Washington State University.

Wonyoung Kim is an associate professor in the Department of Sport Management at Wichita State University.

Please send correspondence to Jinwook Chung, chungj@winthrop.edu 
College athletics in the United States is a critical part of American society, given myriad people attend sport events and consume diverse forms of related products and services. The business of intercollegiate athletics has evolved into a multimillion-dollar industry. Most importantly, football and basketball became the main revenue sources for most intercollegiate athletics. For example, the 13 largest intercollegiate athletic departments generated more than $\$ 100$ million annually from sports, mainly from football and basketball programs (Bloomberg, 2017). In 2018-19, the NCAA's total revenue exceeded $\$ 1$ billion, while college football's top 25 teams generated more than $\$ 2.5$ billion per year in revenue combined (Smith, 2018).

In the eyes of many people, especially the sports fans who are not engaged in the everyday operation of the athletic department, financial status and the business of college sports may look glamorous. However, those schools that do not have premium football programs or basketball programs often face critical financial challenges when generating revenue from media rights, ticket sales, or sponsorship. While the overall size of intercollegiate athletics, especially football and basketball, has increased exponentially, many athletic departments have struggled with their financial operations. Over the past two decades, the volume of athletic department expenses has outpaced revenues except for the few colleges in power five conferences. In particular, the revenue gap between the power five conferences and other schools have continuously increased. For example, the power five conferences pulled in approximately $\$ 6$ billion in revenue, which is $\$ 4$ billion more than all other schools combined (Lavigne, 2016). Thus, sport marketers at small to mid-sized college athletics programs have continued to search for alternative strategies aside from media rights and sponsorship deals to garner more revenue sources.

Though the vast majority of literature on intercollegiate athletics focused on fan motivation, the economic impact of college sports along with the impact of intercollegiate athletics on overall revenue, donation, enhancing school image and reputation, and increasing entertainment to the school and community (Duderstadt, 2000; Gerdy, 2000; Shulman \& Bowen, 2001), less attention was focused on psychic income, which explains psychological and emotional benefits of college sports fans based on the value exchange process. According to Crompton (2004), psychic income is "emotional and psychological benefits residents (in this study college students) perceive they receive, even though they do not physically attend or are involved in organizing them" (p. 49). Crompton's framework has been applied to large-scale sports events such as Super Bowl (Kim \& Walker, 2012), FIFA World Cup (Gibson et al., 2014), and Formula One Grand Prix (Kim et al., 2015), but limited attention was focused on intercollegiate athletics (Kim, 2010; Weight et al., 2019). Psychic income can be applied to college athletics and stakeholders using the social exchange theory (Ap, 1990). College students interact with others regarding the perceived psychological benefits from the value exchange process with the college athletics (e.g., the utilization 
of students fees for the athletics to enhance the athletic facilities) and build the attitude toward the word of mouth and behavioral intentions toward the college athletics (Bandura, 1977).

Focusing on ticket revenues from loyal fans such as community residents and alums can potentially be a solution to these small to mid-sized college athletics programs. As many different factors influence the consumer decision making to support and consume college athletics, there is a need to examine the impact of intangible benefits derived from college athletics toward the university and community. Notably, increasing psychic income variables may be a way to better explain the long-term positive behavior of these loyal fans from the community, university, and alums (Weight et al., 2019). The current study focused on intercollegiate athletics, especially in mid- and small-sized universities, and its fans (e.g., college students) that have the powerful potential of long-term psychological and emotional impact during their college years and later as alums. Therefore, the purpose of this research was to determine the mediating impact of psychic income of college students on attendance, and word of mouth behavior intention.

\section{Literature Review}

According to the psychological continuum model, sports spectators and fans take four steps in increasing their identification (Funk \& James, 2001). First, fans become aware of a specific team. Second, fans acknowledge that they have a favorite team. Third, fans' psychological connection strengthens. Lastly, fans become stable and loyal to the team where they become durable and consistent fans. As the fans' identification strengthens, the attendance behavior likely strengthens. Previous researchers have focused on fans' identification of their attachment to the team. However, Robinson and Trail (2003) explained that the attendance behavior of sports fans is influenced by the points of attachment to player, team, coach, university, community, sport, and level. Kwon and Armstrong (2004) described the points of attachment as a psychological connection toward a sports entity. Many researchers have examined multiple points of attachment variables to explain sports fans' behavior (Funk et al., 2001; Kwon et al., 2005; Woo et al., 2009). Thus, in this study, five points of attachment (e.g., player, team, coach, university, sport) variables were examined to understand college sports fans' behavior. The points of attachment to community and level were excluded from this study because the purpose of this study is to examine the impact of the athletic department toward the college students and not the community or the level of the athletic affiliation.

Based on numerous social impact analysis studies, Crompton (2004) developed seven dimensions of psychic income. Of the seven dimensions, five dimensions can be utilized to examine college athletics' impact on the psychic impact of college students. Collective Self-Esteem (CSE) refers to an individual's increased morale due to being part of the campus community (Brewer \& Gardner, 2004). Emotional Involvement (EM) is a level of involvement that can impact the decision-making process and behavior of consumers (McGehee et al., 2003). Excite- 
ment (EI) of college students can be increased by the athletic department. According to Gibson (1998), excitement is generated by the experience of the individual, which promote positive perception about sports entity, and later elevate consumption behavior. Most athletic departments may not increase the economic impact of the community. However, various teams and events associated with the athletic department can increase positive mental reconstruction such as pride (PR) derived from the community by college students (Johnson et al., 2001). Lastly, social bonding (SB) from the athletic department can increase community interaction such as friendship and social participation (Funk et al., 2002). College students may expect the intercollegiate athletics and related activities to garner various benefits, including but not limited to developing friendship and social bonding, enhancing the image of the university through more media exposure, and enhancing the public reputation of the university.

Therefore, an increased level of above five psychic income factors related to the athletic department can influence the decision-making process and behavior of college students. In this study, psychic income factors were examined as a mediator that can potentially increase the impact of points of attachment variables on behavioral intention (e.g., attendance, support, and word of mouth). Our study attempts to fill the gap in college athletic operation research by providing an understanding of the psychic income of college students.

\section{Method}

\section{Data Collection and Sample}

Data were collected from mid-sized southwest university in the United States that is affiliated with the NCAA Division I level. The initial sample was collected from 779 college students. However, due to incomplete surveys, a total of 537 samples were used for analysis. The sample consisted of $51.4 \%(n=276)$ male and $48.6 \%(n=261)$ female with ages ranging from 19 to 49 years old. Most of the sample was between 20 to 24 years old $(n=316,75.4 \%)$. Semesters attended were relatively even across the sample while $51.9 \%(n=278)$ of the sample resided oncampus. During the data collection year, $53.1 \%(n=284)$ of the sample attended between 5 to 20 college basketball games.

\section{Instrument}

The survey instrument was created based on existing knowledge of the points of attachment research and psychic income paradigm. This study collected data using an online survey consisting of 47 items. A total of 15 points of attachment items (e.g., points of attachment to players, team, coach, sports of basketball, university) were modified from the Points of Attachment Index (PAI) which was utilized in many points of attachment studies (Robinson \& Trail, 2005; Woo et al., 2009). A total of 18 psychic income items (e.g., collective self-esteem, emotional involvement, excitement, pride of institution, social bonding) were modified from Kim's (2010) study on college students' satisfaction level influenced by psychic 
income from the intercollegiate football program. Lastly, the current study measured three behavioral intentions items that were modified from Kim et al's (2011) research and four word of mouth items that were modified from Zeithaml et al's (1996) research along with seven demographic items.

\section{Results}

\section{Measurement Model}

A confirmatory factor analysis (CFA) was conducted to evaluate the psychometric properties of the scales. The correlations among observed variables are presented in Table 1 . Based on the criteria discussed above section, the measurement model fit the data well $\left(\chi^{2} / \mathrm{df}=2212.844 / 674=3.28, \mathrm{CFI}=.94, \mathrm{SRMR}=.05\right.$, RMSEA $=.07)$. All reliability coefficients were greater than .70 , ranging from .81 to .96 (see Table 1). All factor loadings were significant in the predicted direction $(p<.001$; loadings ranging from .67 to .95 ; see Table 2$)$. All the average variance extracted (AVE) values were greater than .50 ranging from .57 to .87 . Thus, the measures showed good evidence of convergent validity and reliability (Hair et al., 2010). Next, three different methods were used to assess evidence of discriminant validity of the factors.

Fornell and Larcker (1981) noted that AVE can also be used to determine discriminant validity. To this effect, the discriminant validity of the construct is determined by comparing the square root of AVE of the variables with the correlation between the variables and all other variables. As displayed in Table 1, the square foot of the AVE for EI is less than its correlation with PAT and the square root of the AVE for CSE is less than its correlation with PR. Other than these two issues, most of the square root of the AVE values are well above the correlation values, hence suggesting the acceptable discriminant validity.

\section{Table 1}

Mean (M), Standard Deviation (STD), CR, and Average Variance Extracted (AVE)

\begin{tabular}{|c|c|c|c|c|c|c|c|c|c|c|c|c|c|c|c|c|}
\hline & M & SD & CR & AVE & SB & $\mathrm{EX}$ & EI & CSE & PR & PAP & PAT & PAC & PAS & PAU & WOM & BI \\
\hline SB & 4.56 & 1.52 & 0.917 & 0.786 & 0.887 & & & & & & & & & & & \\
\hline $\mathrm{EX}$ & 4.83 & 1.42 & 0.9 & 0.751 & $0.866^{* * * *}$ & 0.867 & & & & & & & & & & \\
\hline EI & 4.26 & 1.61 & 0.921 & 0.746 & $0.858 * * *$ & $0.804^{* * *}$ & 0.863 & & & & & & & & & \\
\hline CSE & 4.74 & 1.41 & 0.906 & 0.763 & $0.853^{* * * *}$ & $0.847^{* * *}$ & $0.840^{* * *}$ & 0.873 & & & & & & & & \\
\hline PR & 4.94 & 1.37 & 0.963 & 0.838 & $0.782^{* * * *}$ & $0.842^{* * * *}$ & $0.754^{* * * *}$ & $0.895^{* * * *}$ & 0.916 & & & & & & & \\
\hline PAP & 4.11 & 1.63 & 0.924 & 0.802 & $0.479^{* * * *}$ & $0.462^{* * * *}$ & $0.566^{* * *}$ & $0.533^{3 * *}$ & $0.417^{7 * *}$ & 0.896 & & & & & & \\
\hline PAT & 4.27 & 1.62 & 0.929 & 0.813 & $0.762 * * *$ & $0.711^{* * *}$ & $0.900^{* * *}$ & $0.822^{* * *}$ & $0.753 * * *$ & $0.577^{7 * *}$ & 0.902 & & & & & \\
\hline PAC & 4.29 & 1.63 & 0.93 & 0.817 & $0.582^{* * * *}$ & $0.590^{\circ * * *}$ & $0.659^{* * *}$ & $0.652^{* * * *}$ & $0.618^{* * * *}$ & $0.624^{* * *}$ & $0.687^{* * * *}$ & 0.904 & & & & \\
\hline PAS & 4.32 & 1.77 & 0.915 & 0.783 & $0.611^{* * *}$ & $0.577^{* * *}$ & $0.737 * *$ & $0.647 * * *$ & $0.563^{3 * *}$ & $0.559 * *$ & $0.792 * * *$ & $0.590^{* * *}$ & 0.885 & & & \\
\hline PAU & 4.96 & 1.37 & 0.821 & 0.607 & $0.65 \% * * *$ & $0.679^{* * *}$ & $0.564^{* \text { ** }}$ & $0.681^{1 * * *}$ & $0.711^{1 * * * *}$ & $0.374 * *$ & $0.584 * *$ & $0.522^{* * *}$ & $0.412^{2 * * *}$ & 0.779 & & \\
\hline WOM & 4.46 & 1.54 & 0.957 & 0.847 & $0.773^{* * * *}$ & $0.754^{* * * *}$ & $0.805^{* * * *}$ & $0.817^{* * * * *}$ & $0.764^{* \text { *** }}$ & $0.503^{* * * *}$ & $0.833^{3 * \text { * }}$ & $0.657^{* \text { * * }}$ & 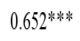 & 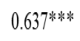 & 0.92 & \\
\hline BI & 5.22 & 1.35 & 0.897 & 0.744 & $0.722^{2 * * *}$ & $0.763^{* * *}$ & $0.692^{* * *}$ & $0.778^{* * * *}$ & 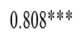 & $0.381^{* * *}$ & $0.704^{* * *}$ & $0.498^{* * * *}$ & $0.527^{7 * * *}$ & $0.761^{1 * * * *}$ & $0.774^{* * * * *}$ & 0.862 \\
\hline
\end{tabular}

Note: ${ }^{* * *} \mathrm{p}>.001$. The square root of AVE is in bold on the diagonal. 


\section{Chung et al.}

\section{Table 2}

\section{Survey Items and Factor Loading}

\begin{tabular}{lc}
\hline Factors and Items & $\boldsymbol{\beta}$ \\
\hline Players (PAP) & .827 \\
PAP1: I identify with the individual players on the team more than with the team. & .933 \\
PAP2: I am a big fan of specific players more than I am a fan of the team. & .923
\end{tabular}

\section{Team (PAT)}

PAT1: I consider myself to be a "real" fan of the University Men's basketball team.

PAT2: I would experience a loss if I had to stop being a fan of the University Men's basketball $\quad .875$ team.

PAT3: Being a fan of __ University Men's basketball team is very important to me.

\section{Coach (PAC)}

PAC1: I am a big fan of __ University Men's basketball coach.

PAC2: I follow the __ University Men's basketball team because I like __ University Men's basketball coach.

PAC3: I am a fan of the __ University Men's basketball team because they are coached by

University Men's basketball coach.

\section{Sports (PAS)}

PAS1: First and foremost, I consider myself a basketball fan.

PAS2: Basketball is my favorite sport.

PAS3: I am a basketball fan at all levels (e.g., high school, college, professional).

\section{University (PAU)}

PAU1: I identify with University rather than with any specific university team.

PAU3: I support _ University as a whole, not just its athletic teams.

\section{Collective Self-Esteem (CSE)}

CSE1: _ University Men's basketball makes me feel good about being a part of

University.

CSE2: __ University Men's basketball increases my sense of belonging to __ University. students together.

\section{Emotional Involvement (EI)}

EI1: Following __ University Men's basketball is a high priority among my campus activities.

stickers, etc.)

\section{Pride of Institution College (PR)}

PR1: I am proud because University Men's basketball is an important component of image. University Men's basketball brings a prestigious sport image to

University.

PR3: I am proud because University Men's basketball increases University's image. University gains a positive image as a result of University men's 


\section{Table 2 (cont.)}

\section{Social Bonding (SB)}

SB1:_ University Men's basketball increases my interactions with various groups.

SB2: University Men's basketball gives more chances to spend time with friends

SB3: University Men's basketball strengthens my friendships at University.

\section{Word-of-Mouth (WOM)}

WOM1: I will say positive things about University Men's basketball game to other people. $\quad .916$ WOM2: I will recommend__ University Men's basketball game to other people.

\section{Attendance (BI)}

BI1: I inted to attend

\section{Simultaneous Equations Model}

The hypothesized model was tested using a simultaneous equations model with AMOS 26 software. Based on the criteria discussed in the previous section, the model fit the data well $\left(\chi^{2} / d f=2864.90 / 764=3.75\right.$, CFI $=.91$, SRMR $=.068$, RMSEA =.072). The path coefficient estimates are reported in Figure 1.

\section{Figure 1}

\section{Research Model}

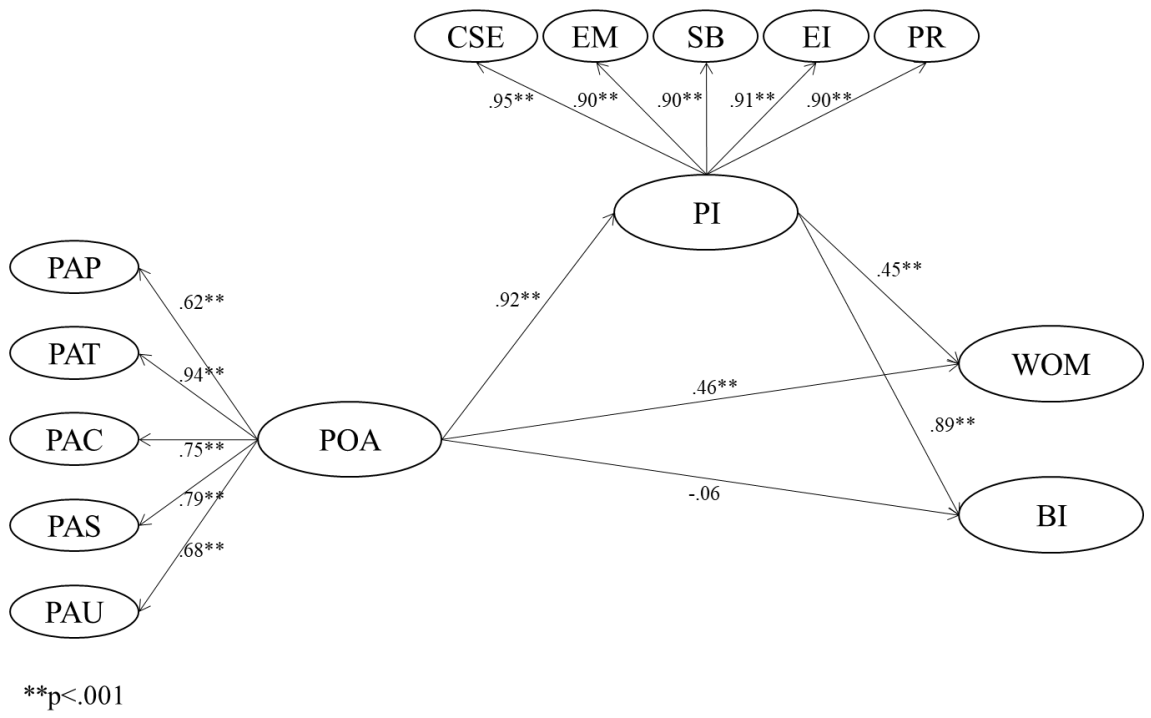

The direct path from POA to BI was not significant (standardized $\gamma=-.06$, S.E. $=.14, p=.55$ ). The direct path from POA to WOM was significant (standardized $\gamma$ $=.46$, S.E. $=.14, p<.001$ ). The direct path from POA to PI was significant (standardized $\gamma=.92$, S.E. $=.08, p<.001$ ). The direct path from PI to BI was significant 
(standardized $\beta=.89$, S.E. $=.12, p<.001$ ). Also, the direct path from PI to WOM was significant (standardized $\beta=.45$, S.E. $=.11, p<.001$ ).

A bootstrapping method (2,000 bootstrap samples) was used to find out the indirect effect of the mediating variable PI on the relation between POA and BI, POA and WOM (Hayes, 2013). The indirect path from POA through PI to BI was significant (standardized $\gamma=.82$, S.E. $=.17, p=.002$ ). Finally, the indirect path from POA through PI to WOM was significant (standardized $\gamma=.41$, S.E. $=.16$, $p=.005$ ). This result indicates that the strength of the indirect path from POA through PI to BI was significantly greater than the direct path from POA to BI. These results indicate that PI fully mediates the relationship between POA and BI. Also, the path from POA through PI to WOM was greater strength compared to the direct path which indicates partial mediation for the relationship.

\section{Discussion and Implications}

The purpose of the current study was to explore the impact of the points of attachment with the mediating factor of the psychic income on behavioral intentions, such as attendance and word of mouth by the college students. Psychic income is the non-monetary aspect of settlement that adds value because it brings intangible benefits to the community. Also, psychic income is the emotional and psychological benefit residents perceive they receive from a local sports team or event. The overall findings from the current study provided further evidence of the significant relationship among the points of attachment, psychic income, and behavioral intentions. The investigation of psychographic attachment to college athletics (e.g., team, coach, player, etc.), perceived psychological benefits, and behavioral intentions are critical for sport administrators in college athletics to develop effective and efficient marketing and public relations strategies. Thus, the outcomes of the current study can provide comprehensive guidelines for the practitioners, in particular, who are associated with the mid- to small-sized college athletics.

From the descriptive analysis, the results suggest that pride $(M=4.94)$ and excitement $(M=4.83)$ were the two highest factors of psychic income. This finding indicates that perceived pride and excitement from the college athletics games can positively influence on behavioral intentions. Thus, administrators of college athletics need to pay attention to increase the sense of pride and excitement among students so that college students can attend more and spread out positive things about games. Regarding the points of attachment, the university $(M=4.96)$ is the highest factor. This finding is critical to college athletics administrators as they have been struggling to grab a positive attitude from students. To be more effectively draw positive consumption behaviors from college students, integrated marketing communication strategies with the association of the university should be developed to increase the level of attachment to the university by students so that they can form a positive disposition toward college athletics and its games. For example, the University of Notre Dame has utilized the university-centered 
athletics campaign: "We Are Notre Dame," which has been a success for garnering positive behavioral support from their students.

As a result of the advanced analysis, this study revealed that there was a positive direct impact by the points of attachment to behavioral intentions while the psychic income also generated a positive indirect impact on the behavioral intentions of college students. These results indicate that psychic income significantly mediates the relationship between the points of attachment and behavioral intentions. Interestingly, the mediating effect of psychic income between the points of attachment and word of mouth (WOM) indicated a partial mediation compared to the points of attachment and behavioral intentions being a full mediation.

The results of the study need to be looked at from an instigator's perspective (i.e., the person who passes the information vs. who participates in an event). WOM is generally considered one of the most significant factors shaping consumer behavior (Daugherty \& Hoffman, 2014). WOM is, however, still an opinion of an instigator that is relatively subjective in nature that could engage easily without much thought process. The results suggest that conveying information does not have to be fully mediated by psychic income. Further, the assessment of psychological benefit does not play a determining role in WOM behavior.

On the other hand, the results suggest that attending an actual event is different from engaging in WOM behavior. Points of attachment is traditionally considered to be an important factor influencing behavioral intentions (Funk et al., 2001; Kwon et al., 2005; Woo et al., 2009). Even so, the current finding suggests that deciding to attend an actual event needs an additional process, such as the assessment of the psychological benefits that the participant will receive. Previous research also indicates that the fan identification and psychic income have strong positive associations when it comes to intercollegiate athletics (Weight et al., 2019). Indeed, the mediation effect of psychic income in our current model indicates a distinctive role in determining two different outcome variables (e.g., WOM, BI).

As well, the provided model suggests that offering college students relevant information about their college athletics teams, players, and coaches may help meet their needs. Their psychic needs may be meet through informing the value of psychic income derived from college athletics, which should then increase positive consumption behaviors toward college athletics. Thus, the current study represents a valuable resource for athletics administrators seeking to strategically build integrated marketing communication strategies that cultivate higher levels of attachment to college athletics by college students and other stakeholders.

The findings of this research also build on previous studies (Kim \& Walker, 2012; Weight et al., 2019) by using psychic income as a mediator to provide a more holistic analysis of the relationship among the points of attachment, perceived psychological benefits, and behavioral intentions. This fills a gap in collegiate research by providing a more nuanced understanding of the psychic income of college students. Namely, an increased level of all five psychic income factors related 
to the athletic department may result in college students being significantly more supportive of college athletics.

Additionally, the current study found that the strength of the indirect path from the points of attachment through psychic income to behavioral intentions was significantly greater than the direct path from points of attachment to behavioral intentions. Even though financial constraints have been a major concern of small to mid-sized college athletics programs, there has been consistent effort in engaging the students by the college athletics. Still, enhancing the effectiveness of those engagement events remains a major challenge to the athletic administrators. The current study confirms the critical role of psychic income on the behavioral attributes of college students; thus, when executing various engagement activities, athletic administrators need to understand the diverse aspects of psychic income to garner positive support from college students. Consider how the College of William and Mary executed student engagement strategies at Kaplan Arena, such as "Tribe Pride Line" and "Gold Rush Game." The strategies put forth by the College of William and Mary included networking events with alumni, free giveaways, pep rallies by the Greek organizations, and personal interactions with athletes and coaches (Maslin, 2018). Such strategies should enhance the psychic income of students, institutional pride, collective self-esteem, and social bonding.

In closing, college athletics can produce a multitude of benefits for college students, including a sense of cohesiveness, community, and social bonding. Thus, developing critical ties between the institution and stakeholders, such as students, should represent a core point of concern for collegiate administrators.

\section{References}

Ap, J. (1990). Residents' perceptions research on the social impacts of tourism. Annals of Tourism Research, 17(4), 610-616.

Bandura, A. (1977). Social learning theory. Prentice-Hall.

Bloomberg. (2017). College sports. https://www.bloomberg.com/quicktake/college-sports-ncaa

Brewer, M. B., \& Gardner, W. (2004). Who is this "we"? Levels of collective identity and self representations. In M. J. Hatch \& M. Schultz (Eds.), Organizational identity: A reader (pp. 66-80). Oxford University Press.

Crompton, J. L. (2004). Beyond economic impact: An alternative rationale for the public subsidy of major league sports facilities. Journal of Sport Management, 9, 14-35.

Daugherty, T., \& Hoffman, E. (2014). eWOM and the importance of capturing consumer attention within social media. Journal of Marketing Communication, 20, 82-102. doi: 10.1080/13527266.2013.797764

Duderstadt, J. (2000). Intercollegiate athletics and the American university: A university president's perspective. The University of Michigan Press.

Fornell, C., \& Larcker, D. F. (1981). Evaluating structural equation models with unobservable variables and measurement error. Journal of Marketing Research, 18(1), 39-50. 
Funk, D. C., \& James, J. (2001). The psychological continuum model: A conceptual framework for understanding an individual's psychological connection to sport. Sport Management Review, 4, 119-150.

Funk, D. C., Mahony, D. F., Nakazawa, M., \& Hirakawa, S. (2001). Development of the Sport Interest Inventory (SII): Implications for measuring unique consumer motives at team sporting events. International Journal of Sports Marketing and Sponsorship, 3, 291-316.

Funk, D. C., Mahony, D. F., \& Ridinger, L. L. (2002). Characterizing consumer motivation as individual difference factors: Augmenting the sport interest inventory (SII) to explain level of spectator support. Sport Marketing Quarterly, 11(1), 33-43.

Gerdy, J. R. (2000). Sports in school: The future of institution. Teachers College Press.

Gibson, H. J. (1998). Sport tourism: A critical analysis of research. Sport Management Review, 1(1), 45-76.

Gibson, H. J., Walker, M., Thapa, B., Kaplanidou, K., Geldenhuys, S., \& Coetzee, W. (2014). Psychic income and social capital among host nation residents: A pre-post analysis of the 2010 FIFA World Cup in South Africa. Tourism Management, 44, 113-122.

Hair, J. F., Black, B., Babin, B., Anderson, R. E., \& Tatham, R. L. (2010). Multivariate data analysis: A global perspective. Pearson Education Inc.

Hayes, A. F. (2013). Introduction to mediation, moderation, and conditional process analysis: A regression-based approach. The Guilford Press.

Johnson, B. K., Groothuis, P. A., \& Whiteside, J. C. (2001). The value of public goods generated by a Major League sports team: The CVM approach. Journal of Sports Economics, 2(1), 6-21.

Kim, Y. K., Trail, G., \& Ko, Y. J. (2011). The influence of relationship quality on sport consumption behaviors: An empirical examination of the relationship quality framework. Journal of Sport Management, 25(6), 576-592.

Kim, W. (2010). College students' psychic income from intercollegiate football and its impact of college satisfaction. (Doctoral dissertation, University of Florida).

Kim, W., Jun, H., Walker, M., \& Drane, D. (2015). Evaluating the perceived social impacts of hosting large-scale sport tourism events: Scale development and validation. Tourism Management, 48, 21-32.

Kim, W., \& Walker, M. (2012). Measuring the social impacts associated with Super Bowl XLIII: Preliminary development of a psychic income scale. Sport Management Review, 15, 91-108.

Kwon, H. H., \& Armstrong, K. L. (2004). An exploration of the construct of psychological attachment to a sport team among college students: A multidimensional approach. Sport Marketing Quarterly, 13, 94-103.

Kwon, H. H., Trail, G. T., \& Anderson, D. F. (2005). Are multiple points of attachment necessary to predict cognitive, affective, conative, or behavioral loyalty? Sport Management Review, 8, 255-270. 
Lavigne, P. (2016, September 6). Rich get richer in college sports as poorer schools struggle to keep up. ESPN. http://www.espn.com/espn/otl/story/_/ $\mathrm{id} / 17447429 /$ power-5-conference-schools-made-6-billion-last-year-gaphaves-nots-grows

Maslin, T. (2018, February 26). Encouraging student engagement with campus athletics. The Flat Hat. http://flathatnews.com/2018/02/26/encouraging-student-engagement-with-campus-athletics/

McGehee, N. G., Yoon, Y., \& Cardnenas, D. (2003). Involvement and travel for recreational runners in North Carolina. Journal of Sport Management, 17(3), 305-324.

Robinson, M. J., \& Trail, G. T. (2003). Motives and points of attachment: Fans versus spectators in Intercollegiate Athletics. Sport Marketing Quarterly, 12(4), $217-227$.

Robinson, M. J., \& Trail, G. T. (2005). Relationships among spectator gender, motives, points of attachment, and sport preference. Journal of Sport Management, 19, 58-80.

Smith, C. (2018, September 11). College football's most valuable teams: Texas A\&M jumps to no. 1. Forbes. https://www.forbes.com/sites/chrissmith/2018/09/11/ college-footballs-most-valuable-teams/\#301256126c64

Shulman, J. L., \& Bowen, W. G. (2001). The game of life: College sports and educational values. Princeton University Press.

Weight, E. A., Huml, M. R., Zagorin, L., Chandran, A., \& Popp, N. (2019). Beyond economic impact: College town resident perceptions of psychic income from intercollegiate athletics. Journal of Issues in Intercollegiate Athletics, 12, $133-153$.

Woo, B., Trail, G. T., Kwon, H. H., \& Anderson, D. (2009). Testing models of motives and points of attachment among spectators in college football. Sport Marketing Quarterly, 18, 38-53.

Zeithami, V. A., Berry, L. L., \& Parasuraman, A. (1996). The behavioral consequences of service quality. Journal of Marketing, 60, 31-46. 